\title{
Extranodal Follicular Dendritic Cell Sarcoma of the Head and Neck Region: Three New Cases, with a Review of the Literature
}

David A. Biddle, M.D., Jae Y. Ro, M.D., Ph.D., Gil S. Yoon, M.D., Yap-Whang H. Yong, M.D., Alberto G. Ayala, M.D., Nelson G. Ordonez, M.D.

Department of Pathology (DAB, JYR, AGA, NGO), The University of Texas M. D. Anderson Cancer Center, Houston, Texas; The Oncology Centre (YHY), Mount Elizabeth Medical Center, Singapore; and Department of Pathology (GSY), Asan Medical Center, Seoul, Korea

Extranodal follicular dendritic cell (FDC) sarcoma of the head and neck region is uncommon, with 16 well-documented cases previously reported (four in the tonsil, four in the pharynx, two in the palate, five in the soft tissue, and one in the thyroid). We here report an additional three cases of extranodal FDC sarcoma in the tonsil (two cases) and pharynx (one case). In these new cases, the neoplastic cells were arranged in diffuse, fascicular, and vaguely whorled growth patterns. A background lymphocytic infiltrate was sprinkled throughout the neoplasms, with focal prominent perivascular cuffing. Scattered multinucleated giant cells were present. Immunohistochemically, tumor cells were strongly and diffusely positive for follicular dendritic cell markers CD21 and CD35. Tumor cells were diffusely positive for fascin and negative for leukocyte common antigen, S-100 protein, cytokeratin, and Epstein-Barr virus (EBV) latent membrane protein-1 (EBV-LMP). EBV was also not detected in the tumor cells by in situ hybridization for EBV-encoded RNAs. FDC sarcomas are probably an underrecognized neoplasm, especially when they occur in extranodal sites in the head and neck region. Two of the three new cases we report were initially misdiagnosed, and five cases of extranodal FDC sarcoma in the head and neck region reported in the recent literature were initially misdiagnosed. Our aim is to complement the current understanding of this neoplasm and alert pathologists to this rare entity in this region to avoid misdiagnosis. Recognition of extranodal FDC sarcoma requires a high index of suspicion, but this tumor has numerous distinctive histological fea-

Copyright (C) 2002 by The United States and Canadian Academy of Pathology, Inc.

VOL. 15, NO. 1, P. 50, 2002 Printed in the U.S.A.

Date of acceptance: September 28, 2001.

Address reprint requests to: Jae Y. Ro, M.D., Ph.D., Department of Pathology, M.D. Anderson Cancer Center, 1515 Holcombe Boulevard, Houston, TX 77030; e-mail: jro@mdanderson.org. tures that should bring the neoplasm into the differential diagnosis. Confirmatory immunohistochemical staining with follicular dendritic cell markers such as CD21 and/or CD35 is essential for the diagnosis. Correct characterization of this neoplasm is imperative given its potential for recurrence and metastasis.

KEY WORDS: CD21, CD35, Follicular dendritic cell sarcoma, Immunohistochemistry, Misdiagnosis, Pharynx, Tonsil.

Mod Pathol 2002;15(1):50-58

Follicular dendritic cell (FDC) sarcoma was first described in 1986 by Monda et al. (1) on the basis of a series of four cases, all of which occurred in lymph nodes. In recent years, there has been a surge of interest in this tumor because of the availability of more sensitive markers to confirm FDC lineage and thus wider recognition. Recently, there have been a number of large series and review articles on this neoplasm (1-28). Approximately 65 cases have been reported to date, with most occurring in lymph nodes. Fewer than one third of the reported cases have been located in extranodal sites $(2,3,5-9,12$, 14, 19-25, 27-33). In 1994, Chan et al. (30) reported the first 2 cases of extranodal FDC sarcoma, both of which occurred in the oral cavity. Since then, the spectrum of FDC sarcoma in extranodal sites has greatly expanded to include locations throughout the body $(2,3,5-9,12,14,19-25,29,30,34)$. The tonsil, nasopharynx, pancreas, peripancreatic, and peritoneal tissues are the most common extranodal sites. Extranodal FDC sarcomas are rare, and only 16 cases in the head and neck region have been reported in the literature $(2,5-9,12,28-30,35)$.

We here report three additional cases of FDC sarcoma, two of which were initially misdiagnosed. Two of the cases originated in the tonsil and 1 in the nasopharynx and oropharynx. Our aim in reporting 
these cases is to broaden the clinicopathologic spectrum of FDC sarcoma to aid pathologists in the recognition of this neoplasm.

\section{MATERIALS AND METHODS}

Tissue specimens were fixed in $10 \%$ buffered formalin and routinely processed for light microscopy. For histologic evaluation, 5- $\mu \mathrm{m}$-thick sections were cut and stained with hematoxylin and eosin (H\&E).

Immunohistochemical studies were performed on formalin-fixed, paraffin-embedded tissue sections using the avidin-biotin-peroxidase complex (ABC) method (36) in a DAKO Auto-Stainer (Carpinteria, CA). The primary antibodies used were a "cocktail" of three anticytokeratin mouse monoclonal antibodies (Boehringer-Mannheim, Indianapolis, IN; 1:200 dilution; clones AE1 and AE3; and Beckton-Dickinson, Mountainview, CA; 1:5; CAM 5.2) that recognize a wide spectrum of highand low-molecular weight cytokeratin peptides, monoclonal antibodies to CD45 (DAKO; 1:300; clones PD7/26 and 2B11), CD21 (DAKO; 1:5; clone 1F8), CD35 (DAKO; 1:10; clone Ber-MAC-DRC), fascin (DAKO; 1:100; clone 55k.2), Epstein-Barr Virus Latent Membrane Protein-1 (DAKO; 1:50; CS1-4) and a "cocktail" of a mouse monoclonal antibody and a rabbit polyclonal antibody to $S-100$ protein (Ventana, Tucson, AZ, 1:2, clone 15E2E2). The immunoperoxidase staining was performed by using the LSAB2 peroxidase kit (DAKO). To enhance the immunostaining, a heat epitope retrieval procedure was performed using a Black and Decker vegetable steamer (Shelton, CT). Briefly, deparaffinized sections were placed in a thermoresistant container filled with citrate buffer solution ( $\mathrm{pH}$ 6.0), steamed for 45 minutes, and then cooled for 20 minutes before staining. The antigen-antibody reaction was visualized using 3-amino-9-ethylcarbazole as chromogen. To evaluate the specificity of the antibody, tissues known to have positive and negative reactions were used as controls.

In situ hybridization for Epstein-Barr virus (EBV)encoded RNAs was performed on paraffin sections using a fluorescein-conjugated peptide nucleic acid probe (DAKO; Y5200).

\section{RESULTS}

Clinical Data

\section{Case 1}

A 48-year-old woman presented at a Korean hospital with an enlarged, hard, fixed lymph node of the left submandibular area that had been present for about 1 month. The patient was otherwise in good health. The clinical impression was that the lesion represented either metastatic carcinoma or lymphoma.

A fine needle aspiration of the mass was performed, and the diagnosis was of an "atypical mesenchymal lesion with inflammation suspicious for inflammatory pseudotumor or low grade malignancy." The patient underwent a left tonsillectomy with a left radical neck dissection. The tonsil measured $3.5 \times 3.5 \times 2 \mathrm{~cm}$ and contained an ill-defined, yellow-white firm mass with hemorrhage measuring $1.5 \times 1.2 \times 1.0 \mathrm{~cm}$. One of the 44 lymph nodes in the specimen was involved by tumor. The involved lymph node measured $5 \mathrm{~cm}$ in greatest dimension and was completely replaced by tumor. The patient has remained disease-free for 6 months after surgery.

\section{Case 2}

A previously healthy 48-year-old man living in Singapore sought medical attention because of pain in the tonsillar area. Intraoral examination revealed a swollen, enlarged right tonsil. No neck masses or lymphadenopathy was noticed. The clinical impression was chronic tonsillitis.

A right tonsillectomy was performed. The right tonsil measured $3.5 \times 2 \times 2 \mathrm{~cm}$ and contained a multinodular submucosal mass. The left tonsil was not enlarged and was not surgically removed. The patient's health was otherwise excellent. The patient has remained disease free for 8 months after surgery.

\section{Case 3}

A 33-year-old man living in the United States first sought medical care for shoulder pain in 1998 and subsequently developed a lump near his right ear in November 1998, at which time magnetic resonance imaging showed a mass in the right base of the patient's skull in the retroauricular area. A biopsy of the right oropharynx and nasopharynx was performed, with a diagnosis of malignant schwannoma. The patient underwent surgery and later, radiation therapy. Ten months later, masses in the right chest and left lung were identified that were consistent with metastatic tumors. A needle biopsy of the tumor in the lower aspect of the left posterior lung was performed, with a diagnosis of metastatic sarcoma. The patient was referred to M. D. Anderson Cancer Center for chemotherapy. The patient was otherwise in good health previously, without medical or surgical problems.

\section{Histopathologic Findings}

Two tonsillectomy specimens and one pharyngeal biopsy specimen were examined. All three specimens contained neoplasms that were relatively well circumscribed, with pushing borders 
(Fig. 1). Several growth patterns were observed within the tumors, including characteristic storiform (Fig. 2), interlacing fascicular, and diffuse patterns. Neoplastic cells consisted of uniform oval-to-spindle cells with smooth nuclear membranes and fine to coarsely speckled chromatin with distinct nucleoli (Fig. 3). The cells had pale eosinophilic cytoplasm and showed a syncytial growth pattern with ill-defined cell borders. Neoplastic multinucleated cells (Figs. 3, 4) and occasional nuclear pseudoinclusions were seen. A constant feature in all cases was a background of variable numbers of small mature lymphocytes scattered throughout the tumor, as well as cuffing around vessels (Fig. 5). Dilated blood vessels with an irregular configuration and small vessels with thick hyalinized walls were also present. The mitotic rate in the tonsillar neoplasms was low $(0-3$ mitoses per 10 high-power field), and nuclear pleomorphism was not observed. Nuclear pleomorphism and an increased mitotic rate (8 mitoses per 10 high-power field) were observed in both the oropharyngeal neoplasm and lung metastasis in Case 3 (Fig. 6). The histology of the primary tumor in Case 3 was identical to that of the metastasis to the lung. Necrosis was absent in all three cases.

The paraffin blocks were available in all three cases for immunohistochemical analysis. Tumor cells, including giant cells, in Cases 1 and 2 were strongly and diffusely positive for the FDC markers CD21 and CD35. Tumor cells in Case 3 were diffusely positive for CD21 and focally positive for CD35. These markers highlighted the delicate interconnecting cell processes of the tumor cells, forming whorls and complex networks (Fig. 7A-B). Tumor cells in all three cases were positive for fascin with diffuse cytoplasmic staining and were negative for S-100 protein, cytokeratin, EBV latent mem-

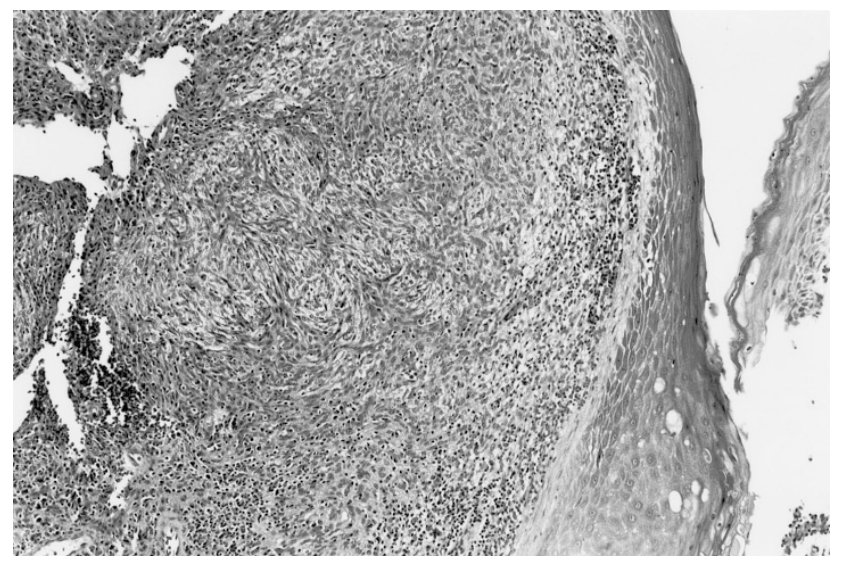

FIGURE 1. Case 1. Extranodal follicular dendritic cell sarcoma located beneath the stratified epithelium of the tonsil. The tumor is well circumscribed with pushing borders. Note the characteristic sprinkling of small lymphocytes throughout the tumor (hematoxylin and eosin stain, original magnification, $40 \times$ ).

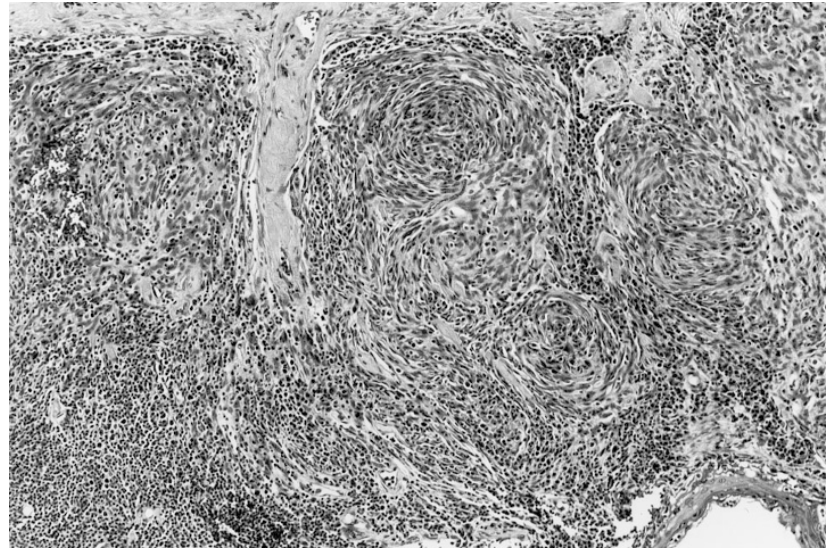

FIGURE 2. Case 2. Focally, the tumor forms vague circular whorls in a storiform growth pattern. Small lymphocytes and plasma cells are intermingled with syncytial-appearing neoplastic cells with smooth nuclear membranes (hematoxylin and eosin stain, original magnification, $100 \times)$.

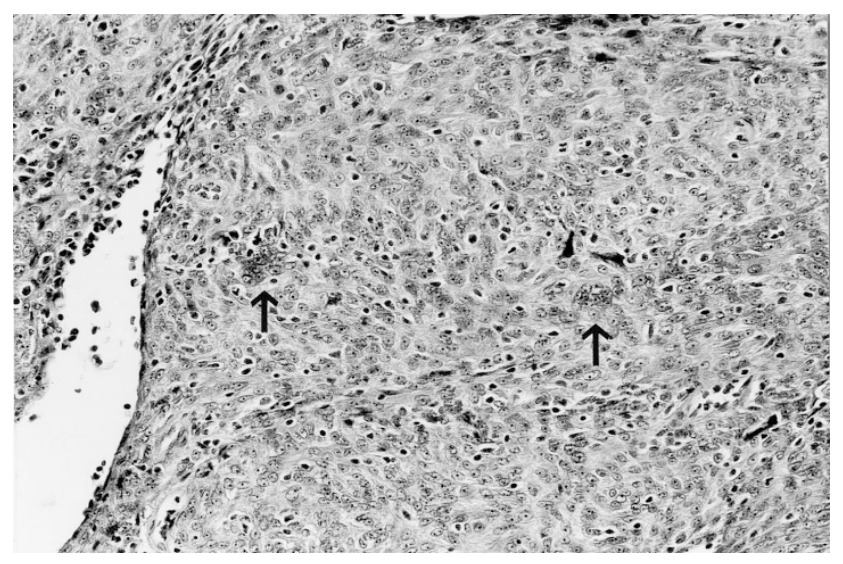

FIGURE 3. Case 2. The tumor cell borders are indistinct, and the nuclei contain coarsely speckled chromatin with distinct nucleoli. Note the scattered multinucleate giant cells ( $\uparrow$ ) (hematoxylin and eosin stain, original magnification, $200 \times$ ).

brane protein-1 (EBV-LMP), EBER, and leukocyte common antigen.

\section{DISCUSSION}

FDC sarcoma is an uncommon neoplasm of antigen-presenting cells of the B-cell follicles of lymphoid organs. Follicular dendritic cells are required for germinal centers of B-cell follicles, which are present not only in lymph nodes but also extranodally, either as acquired lymphoid tissue or as part of the organized constitutive lymphoid tissue (37). It is therefore reasonable that tumors with FDC differentiation arise at extranodal locations. FDC sarcomas in extranodal sites have been found in locations throughout the body, including the pancreas, tonsil, peritoneum, palate, pharynx, stomach, small intestine, colon, mesentery, mesocolon, spleen, mediastinum, liver, thyroid, lung, 


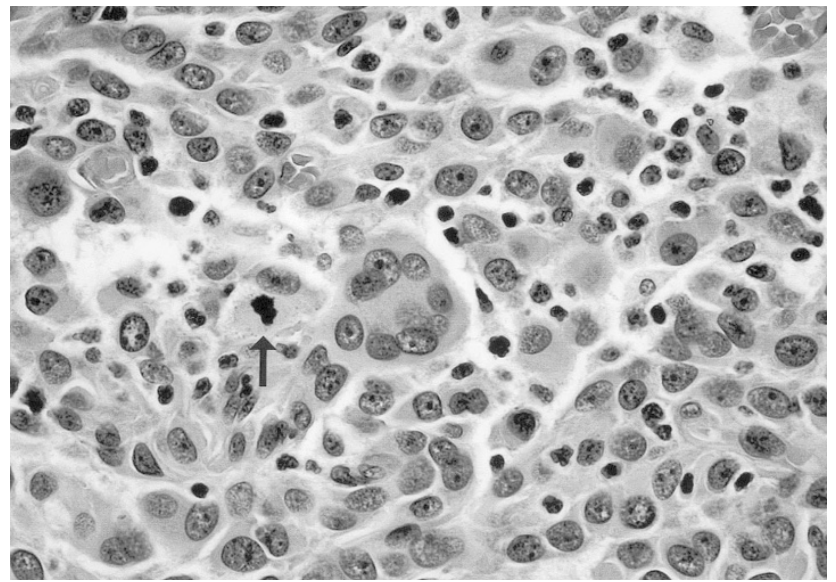

FIGURE 4. Case 1. Focally multinucleated cells and mitotic figures $(\uparrow)$ are found within the tumor (hematoxylin and eosin stain; original magnification, $600 \times)$.

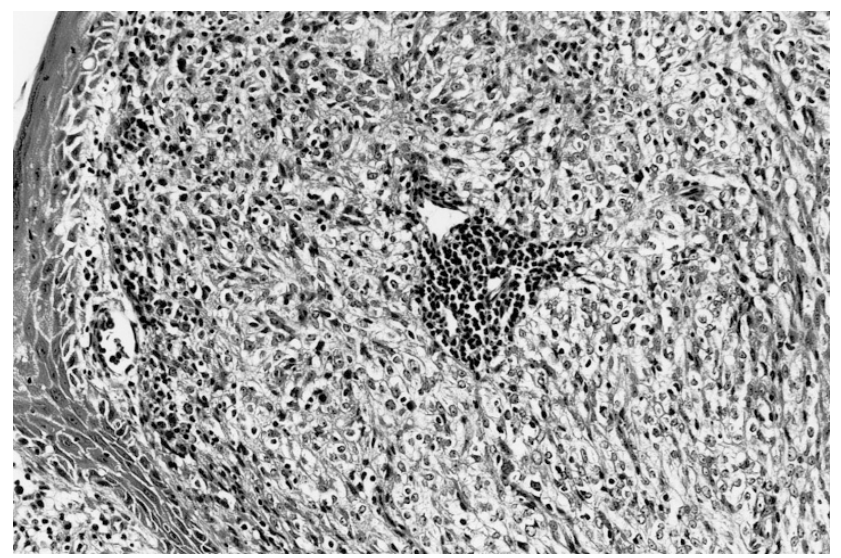

FIGURE 5. Case 1. There is a background of small mature lymphocytes scattered throughout the tumor, as well as cuffing around a vessel (hematoxylin and eosin stain; original magnification, $100 \times$ ).

retroperitoneum, and breast $(2,3,5-9,12,14,19-$ $25,27-33)$.

Nineteen cases of extranodal FDC sarcoma of the head and neck region have been reported in the literature, including the three cases from this report (six in the tonsil, five in the pharynx, two in the palate, five in the soft tissue, and one in the thyroid; $2,5-9,12,28-30,35)$. Eleven cases have occurred in women and eight, in men. Patient age at diagnosis ranged from 14 to 76 years (mean, $42.2 \mathrm{y}$ ). Tumor size ranged from 1 to $14 \mathrm{~cm}$ in maximum dimension (mean, $4.8 \mathrm{~cm}$ ); size was not recorded for four tumors. Follow-up was available for 17 (89\%) of the 19 patients and ranged from 6 months to 15 years (mean, 2.75 y). Of these 17 patients, 9 (53\%) have remained disease free after surgery and $8(47 \%)$ have had a recurrence; 10 (59\%) have had evidence of metastasis or tumors with lymphatic permeation. Of these latter 10 patients, $5(50 \%)$ had distant metastasis to the lung, brain, or both, and 5 (50\%) had tumors with lymphatic permeation or local me-

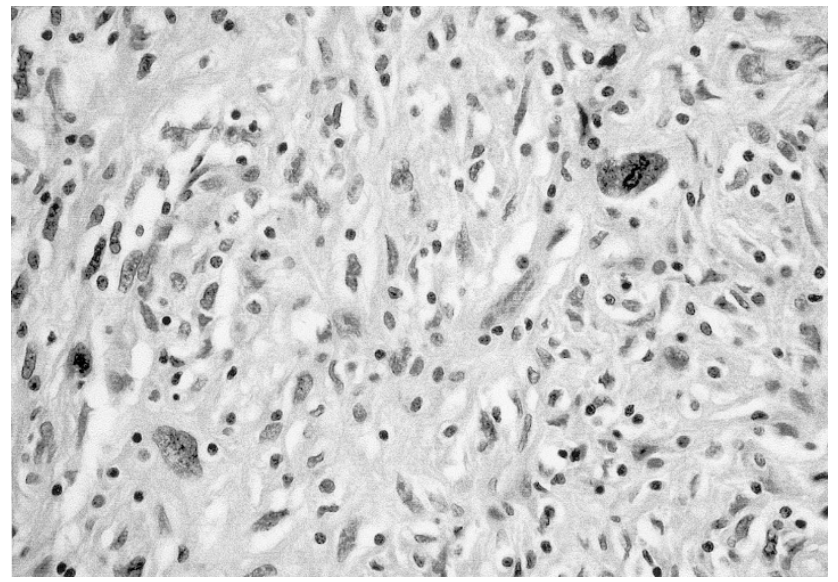

FIGURE 6. Case 3. Tumor cells show nuclear pleomorphism (hematoxylin and eosin stain; original magnification, $400 \times$ ).

tastasis to lymph nodes. One $(5.9 \%)$ of the 17 patients has died of disease. Nine patients $(47 \%)$ of the 19 were treated with radiation, and 5 patients (26\%) were treated with chemotherapy (Table 1). Three (16\%) of the 19 extranodal FDC sarcomas had at least one unfavorable histologic attribute (pleomorphism, $>5$ mitoses per 10 high-power field, necrosis) (6).

Awareness of FDC sarcoma and the ability to recognize this tumor are important, because the tumor closely mimics a wide variety of other tumors and tumor-like lesions. Often, FDC sarcoma is not considered in the differential diagnosis, especially when they occur in extranodal sites. Even with immunohistochemical studies, the diagnosis of FDC sarcoma may be missed because FDC markers are not included among the routine panel of antibodies used for the investigation of undifferentiated neoplasms.

The following seven cases of extranodal FDC sarcoma of the head and neck illustrate how elusive the diagnosis of FDC sarcoma can be. FDC sarcoma was not the initial diagnosis in two of the three new cases in this report and was not the initial diagnosis in five cases of extranodal FDC sarcoma of the head and neck region reported in the literature $(5,8,9$, 29). Case 1 in our report was initially diagnosed as an "atypical mesenchymal lesion with inflammation suspicious for inflammatory pseudotumor or low grade malignancy." Case 3 was initially diagnosed as a malignant schwannoma.

The extranodal FDC sarcoma of the parapharyngeal region reported by Desai et al. (29) was initially diagnosed as a parapharyngeal ectopic meningioma. One year after diagnosis, the patient developed a recurrence at the same site. Reexcision showed an identical tumor with additional features of lymphatic embolization and angioinvasion. A revised diagnosis of extranodal FDC sarcoma was 


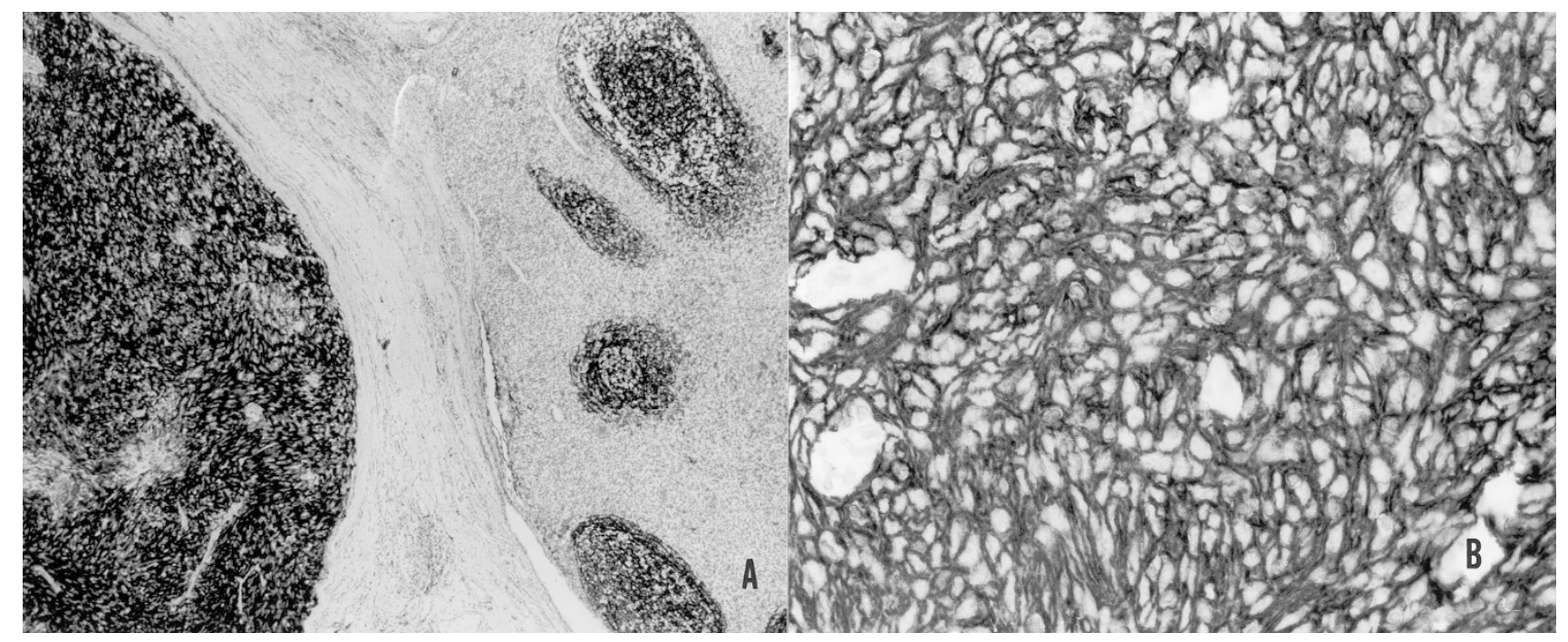

FIGURE 7. Immunostains for CD21 and CD35, both for Case 1. (A) Immunostain for CD21 stains the tumor cells on the left strongly and diffusely (paraffin immunohistochemical stain; original magnification, 40×). (B) Immunostain for CD35 highlights complex branching networks of neoplastic follicular dendritic cells (paraffin immunohistochemical stain; original magnification, $400 \times$ ).

made after the tumor cells stained positively for CD21 and CD35.

The extranodal FDC sarcoma of the palate reported by Chan et al. (30), was initially diagnosed as "probably acinic cell carcinoma" on biopsy. Radiation therapy was applied to the entire oral cavity and upper anterior lymphatic chain. Later, wide local excision was performed, and "an exact histogenetic diagnosis could not be rendered from the specimen because of negative immunohistochemical staining with a wide panel of antibodies" (30). A revised diagnosis of FDC sarcoma was retrospectively made. The FDC sarcoma of the thyroid reported by Galati et al. (8) was initially diagnosed as a poorly differentiated non-small cell carcinoma after fine needle aspiration.

Araujo et al. (7) reported a case of extranodal FDC sarcoma of the palate. The clinical impression of the mass was that of a benign salivary gland tumor. The authors' first impression of the tumor histologically was that of a fibrous histiocytoma. The sprinkling of lymphocytes within the tumor led the authors to suspect FDC sarcoma. FDC markers were applied using CD21 and CD35 confirming the diagnosis of FDC sarcoma.

Choi et al. (9) reported a case of FDC sarcoma of the left neck that was initially diagnosed as a "malignant ectopic thymic tumor consistent with CASTLE (carcinoma showing a thymus-like element)." Eleven years later, after chemotherapy, radiation therapy, and metastasis to the brain and lung, a revised diagnosis of FDC sarcoma was made after CD21 and CD35 were performed on the lung metastasis. Choi et al. (9) also reported another case of FDC sarcoma of the left cervical region as being CASTLE. A correct diagnosis of FDC sarcoma was not reached until pulmonary metastases were identified $>18$ months later, when follicular dendritic cell markers were performed.

Recently, through a personal communication, we learned of a primary FDC sarcoma involving the tonsil that was clinically suspected to be a carcinoma. The frozen-section diagnosis was, "malignant neoplasm, high grade carcinoma versus lymphoma." After consultation, the correct diagnosis was suspected; it was later confirmed after immunohistochemical staining for CD21 was performed. This case was not included in this series because it is currently in press in the American Journal of Otolaryngology.

The head and neck region is not the only location in which extranodal FDC sarcoma has been initially misdiagnosed. Three cases of extranodal FDC sarcoma involving the gastrointestinal tract were initially misdiagnosed as an intraabdominal stromal tumor (21), a diffuse large cell lymphoma of the liver (14), and an unclassified nonepithelial lowgrade malignant neoplasm of the mesentery (23).

At least three case reports in the literature describing primary ectopic meningioma of the tonsils and retroperitoneum may have been FDC sarcomas (38-41). All three cases displayed histologic features characteristic of FDC sarcoma, consisting of "sheets of ovoid to spindle-shaped cells with fine nuclear chromatin and ill-defined cell membranes forming nests and many distinct whorls" (38). Photographs of these tumors show a background of mature lymphocytes scattered throughout the neoplastic cells, as well as perivascular cuffing of lymphocytes. One of the cases was classified as an atypical meningioma of the tonsil because of increased mitotic activity (39). Ultrastructural studies were not performed 


\begin{tabular}{|c|c|c|c|c|c|}
\hline Report (year) & $\begin{array}{l}\text { Sex/Age } \\
\text { (y) }\end{array}$ & Tumor Location & Tumor Size & Initial Treatment & Follow-Up \\
\hline Nayler (2), 1996 & $\mathrm{~F} / 18$ & Tonsil & $4 \times 2 \times 2 \mathrm{~cm}$ & Surgery and chemotherapy & None. \\
\hline $\begin{array}{l}\text { Perez-Ordonez (5), } \\
1996\end{array}$ & $\mathrm{~F} / 62$ & Tonsil & NA & Surgery & NED for $1 \mathrm{y}$. \\
\hline Chan (6), 1997 & $\mathrm{~F} / 63$ & $\begin{array}{l}\text { Palate and } \\
\text { retromolar } \\
\text { trigone }\end{array}$ & $3 \times 3 \times 2 \mathrm{~cm}$ & $\begin{array}{l}\text { Surgery and radiation therapy } \\
(57.7 \mathrm{~Gy})\end{array}$ & NED for $4.5 \mathrm{y}$. \\
\hline Chan (6), 1997 & $\mathrm{M} / 44$ & Tonsil & $1.5 \mathrm{~cm}$ & Surgery (tonsillectomy) & NED for $3 \mathrm{y}$. \\
\hline Chan (6), 1997 & $\mathrm{M} / 32$ & Tonsil & $8 \mathrm{~g}$ & $\begin{array}{l}\text { Surgery (tonsillectomy), followed } \\
\text { by radiation therapy }\end{array}$ & $\begin{array}{l}\text { Local recurrence after } 4.5 \mathrm{y} \\
\text { with cervical lymph } \\
\text { node metastases, } \\
\text { treated with additional } \\
\text { surgery. }\end{array}$ \\
\hline Chan (6), 1997 & $\mathrm{M} / 17$ & $\begin{array}{l}\text { Soft tissue of } \\
\text { neck }\end{array}$ & $11 \times 8.5 \times 3.5 \mathrm{~cm}$ & $\begin{array}{l}\text { Biopsy, followed by } 8 \mathrm{wk} \text { of } \\
\text { chemotherapy, followed by } \\
\text { excision of residual tumor }\end{array}$ & $\begin{array}{l}>95 \% \text { response to } \\
\text { chemotherapy. No } \\
\text { long-term follow-up. }\end{array}$ \\
\hline Chan (6), 1997 & $\mathrm{~F} / 40$ & $\begin{array}{l}\text { Parapharyngeal } \\
\text { mass }\end{array}$ & $7 \times 3 \times 2 \mathrm{~cm}$ & Surgical excision & $\begin{array}{l}\text { Local recurrence } \\
\text { (lymphatic } \\
\text { permeation) at } 1 \mathrm{y} \text {. }\end{array}$ \\
\hline Chan (6), 1997 & $\mathrm{~F} / 25$ & $\begin{array}{l}\text { Soft tissue of } \\
\text { neck }\end{array}$ & $7 \times 6 \times 3 \mathrm{~cm}$ & $\begin{array}{l}\text { Radical neck dissection and } \\
\text { postoperative radiation } \\
\text { therapy }\end{array}$ & $\begin{array}{l}20 \text { mo after diagnosis, } \\
\text { chest x-ray showed } \\
\text { multiple nodules in } \\
\text { lungs. Treated with } \\
\text { chemotherapy. }\end{array}$ \\
\hline Lin (35), 1997 & $\mathrm{~F} / 76$ & Left neck & $7 \mathrm{~cm}$ & Surgery & $\begin{array}{l}\text { Local recurrence and } \\
\text { metastasis to chest } \\
\text { wall after } 3.5 \mathrm{y} \text {. DOD } \\
\text { after } 4 \mathrm{y} \text {. }\end{array}$ \\
\hline $\begin{array}{l}\text { Beham-Schmid } \\
\text { (12), } 1998\end{array}$ & $\mathrm{M} / 44$ & Nasopharynx & $\begin{array}{l}2 \mathrm{~cm} \text { maximum } \\
\text { dimension }\end{array}$ & Surgery and radiation therapy & NED for $20 \mathrm{mo}$ \\
\hline Araujo (7), 1999 & $\mathrm{M} / 14$ & Hard palate & $1.5 \mathrm{~cm}$ & Surgery & NED for 5 mo. \\
\hline Desai (29), 1999 & $\mathrm{~F} / 45$ & $\begin{array}{l}\text { Parapharyngeal } \\
\text { region }\end{array}$ & $6 \times 3 \times 3 \mathrm{~cm}$ & Surgery and radiation therapy & $\begin{array}{l}\text { Recurrence after } 1 \mathrm{y} \text { with } \\
\text { lymphatic } \\
\text { embolization and } \\
\text { angioinvasion. }\end{array}$ \\
\hline Galati (8), 1999 & $\mathrm{~F} / 65$ & Thyroid & $1.5 \mathrm{~cm}$ & $\begin{array}{l}\text { Surgery (complete thyroidectomy } \\
\text { and radical neck dissection), } \\
\text { and radiation therapy }\end{array}$ & $\begin{array}{l}\text { NED for } 3 \text { y } 4 / 17 \\
\text { metastatic lymph } \\
\text { nodes, one with } \\
\text { extracapsular spread at } \\
\text { initial surgery. }\end{array}$ \\
\hline Choi (9), 2000 & $\mathrm{~F} / 28$ & $\begin{array}{l}\text { Soft tissue of } \\
\text { neck }\end{array}$ & NA & Surgery & $\begin{array}{l}\text { Recurrence after } 15 \text { y with } \\
\text { metastasis to brain } \\
\text { and lung. Treated with } \\
\text { radiation and } \\
\text { chemotherapy. }\end{array}$ \\
\hline Choi (9), 2000 & $\mathrm{~F} / 66$ & $\begin{array}{l}\text { Soft tissue of } \\
\text { neck }\end{array}$ & $14 \times 11 \times 9$ & $\begin{array}{l}\text { Radical neck dissection and } \\
\text { postoperative radiotherapy }\end{array}$ & Metastasis to right lung. \\
\hline Chan (28), 2001 & $\mathrm{M} / 34$ & Nasopharynx & $1 \mathrm{~cm}$ & $\begin{array}{l}\text { Chemotherapy followed by } \\
\text { surgery }\end{array}$ & NED for $3 y$. \\
\hline Present series & $\mathrm{F} / 48$ & Left tonsil & $1.5 \times 1.2 \times 1.0 \mathrm{~cm}$ & $\begin{array}{l}\text { Left tonsillectomy and radical } \\
\text { neck dissection }\end{array}$ & $\begin{array}{l}\text { NED for } 3 \text { mo. } 1 / 44 \text { lymph } \\
\text { node involved at initial } \\
\text { surgery. }\end{array}$ \\
\hline Present series & $\mathrm{M} / 48$ & Right tonsil & $3.5 \times 2 \times 2 \mathrm{~cm}$ & Right tonsillectomy & $\begin{array}{l}\text { NED for } 5 \text { mo after } \\
\text { surgery. }\end{array}$ \\
\hline Present series & $\mathrm{M} / 33$ & $\begin{array}{l}\text { Nasopharynx, } \\
\text { oropharynx }\end{array}$ & NA & $\begin{array}{l}\text { Surgery and postoperative } \\
\text { radiation therapy }\end{array}$ & $\begin{array}{l}\text { Bilateral lung metastasis } 10 \\
\text { mo after initial biopsy. }\end{array}$ \\
\hline
\end{tabular}

NA, not available; NED, no evidence of disease; DOD, dead of disease.

in the tonsillar neoplasms but were supportive of FDC sarcoma in the retroperitoneal mass. Immunohistochemical staining for follicular dendritic cell differentiation was not performed in any of the cases. Ectopic meningiomas and FDC sarcoma share histologic features, EMA immunoreactivity, and many similar ultrastructural features.

Although a diagnosis of FDC sarcoma can be suspected or presumptively made from the histologic findings, it is mandatory to confirm the diag- nosis by immunohistochemistry. CD21 and CD35, directed against the $\mathrm{C} 3 \mathrm{~d}$ and $\mathrm{C} 3 \mathrm{~b}$ receptors, respectively, and CNA.42 are the most widely used markers demonstrating FDC differentiation $(28,42)$. These markers work well on formalin-fixed, paraffin-embedded materials; however, only CD21 and CD35 are commercially available. Other FDCspecific markers useful for confirming a diagnosis of FDC sarcoma include Ki-M4, Ki-M4p, R4/23, and Ki-FDC1p (43-47). 
Although FDC immunohistochemical markers are not available in many labs, to make a diagnosis of FDC sarcoma, the cells, by definition, must stain positively for FDC markers. Thus, if a case is suspected of being a FDC sarcoma, it must be sent to an immunohistochemistry lab that does offer markers for FDC differentiation. Staining is sometimes very focal in FDC sarcomas; therefore, it may be worth performing the stain on additional tissue blocks if the diagnosis is strongly suspected and the staining is negative (37). Routine immunohistochemical markers available in most labs are widely variable in positivity in FDC sarcoma and include vimentin, EMA, S100, CD68, desmoplakin, musclespecific actin, and leukocyte common antigen (2, $5-9,12,29,30)$. FDC sarcomas are consistently negative for cytokeratins, HMB-45, CD31, and CD34. Many of these stains may further increase one's suspicion of a FDC sarcoma; however, none of these routine markers offers any more evidence for FDC differentiation than the characteristic histology described earlier. Ultrastructural studies are desirable to have when making a diagnosis of FDC sarcoma but are not diagnostic or necessary (37). Thus, if FDC sarcoma is suspected on H\&E sections, it is imperative to obtain additional immunohistochemical stains to prove follicular dendritic cell differentiation of the cells.

The three cases of extranodal FDC sarcoma in this series are the first in the English literature reported to stain with fascin. All three cases were diffusely positive for fascin, with strong cytoplasmic immunoreactivity. There are also a small number of reports in the literature that describe fascin immunoreactivity in nodal FDC sarcomas. Fascin is an actin-binding protein expressed in follicular and interdigitating dendritic cells and is important for the development of dendrites (48). It is therefore not surprising that all three cases in this series were immunoreactive for fascin. It is likely that fascin will be positive in most nodal and extranodal FDC sarcomas; however, additional studies will be required to prove this. Although fascin is likely to be a sensitive marker for FDC sarcomas, it is not specific and stains many other neoplasms of dendritic cell origin, including interdigitating reticulum cell sarcoma, juvenile xanthogranuloma, soft tissue dendrocytomas, Rosai-Dorfman lesions, and ReedSternberg cells (48-53).

The differential diagnosis of extranodal FDC sarcoma involving the head and neck is broad; however, the possibility of FDC sarcoma should especially be entertained in neoplasms resembling ectopic meningioma, thymoma-like tumors occurring outside the mediastinum, tumors resembling malignant fibrous histiocytoma with admixed lymphocytes, and unusual cytokeratin-negative neoplasms (6). Other neoplasms in the differential di- agnosis include undifferentiated nasopharyngeal carcinoma, synovial sarcoma, interdigitating reticulum cell sarcoma, spindle cell carcinoma, minor salivary gland tumors, malignant peripheral nerve sheath tumor, acinic cell carcinoma, metastatic carcinoma, malignant melanoma, large-cell lymphoma, inflammatory pseudotumor, angiosarcoma, and Hodgkin's lymphoma. All neoplasms in the differential diagnosis lack follicular dendritic cell differentiation and are easily excluded if FDC sarcoma is considered and immunohistochemical staining with FDC markers is applied. Chan et al. (6) extensively reviewed the differential diagnosis of FDC sarcoma in the above-listed neoplasms and have described in detail the most salient histologic and immunohistochemical features helpful for distinguishing these tumors from FDC sarcoma. Extranodal FDC sarcoma has numerous distinctive histological features that should bring it into the differential diagnosis. Syncytial sheets of cytokeratin-negative cells with focal storiform areas arranged in centripetal whorls reminiscent of meningioma in a background of mature lymphocytes, and focal multinucleate giant cells should bring FDC sarcoma into consideration regardless of the site.

Although it was originally known as follicular dendritic cell tumor, Chan et al. (6) proposed the name follicular dendritic cell sarcoma to emphasize the clinical behavior of the neoplasm as a sarcoma rather than as a lymphoma. Until recently, FDC sarcoma was considered an indolent tumor with a tendency for local recurrence but with a low risk of metastasis. Recent larger reports with longer follow-up have concluded that FDC sarcoma is more aggressive and should be considered at least an intermediate-grade malignancy (6). At least $40 \%$ of documented FDC sarcomas have recurred, and $25 \%$ have metastasized (6). The most common sites of metastasis include the lung, liver, peritoneum, and lymph nodes. Chan et al. (6) documented a mortality rate for FDC sarcoma of $16.7 \%$ (7 of 42 cases).

FDC sarcoma has been associated with EBV and with hyaline-vascular type Castleman's disease. EBV has been documented to be positive in a small percentage of cases of FDC sarcoma; however, all cases have occurred in the liver and spleen, with morphologic features mimicking inflammatory pseudotumor $(6,21,22)$. No cases of extranodal FDC sarcomas reported in the head and neck region have been associated with $\operatorname{EBV}(5,6,12$, 28, 54).

Thirteen cases of FDC sarcoma have been reported to be associated with Castleman's disease, mostly hyaline-vascular type and rarely, mixed or plasma cell type. Only two of the cases associated with Castleman's disease were located in the head and neck region $(4,6,26,28,35,37)$. Because most 
cases of Castleman's disease were merely discovered in the same anatomic site as Castleman's disease, it has been suggested that associated Castleman's disease-like changes may represent only a reaction to FDC sarcoma. Recently, however, stronger evidence has demonstrated, with sequential biopsies over the period of 11 years, clear progression from an FDC proliferation in the setting of hyalinevascular type Castleman's disease to FDC sarcoma (28). Additional studies will be required to establish whether there is a clonal relationship between Castleman's disease and FDC sarcoma. EBV does not appear to play a role in the transformation process of Castleman's disease to FDC sarcoma because all cases associated with Castleman's disease have been EBV negative $(6,28,54)$.

Extranodal FDC sarcomas of the head and neck will probably continue to be an underrecognized neoplasm. Recognition requires a high index of suspicion, but extranodal FDC sarcoma has numerous distinctive histological features that should serve as clues to bring the neoplasm into the differential diagnosis and thus prevent misdiagnosis, as occurred in two of the three cases we report and in 8 cases reported previously in the literature $(8,9,14$, $21,23,29,30,35)$. Once FDC sarcoma is suspected histologically, immunohistochemical stains for follicular dendritic cell differentiation must be performed to avoid the potential for misdiagnosis. Greater awareness of the morphologic spectrum of FDC sarcoma and appropriate immunostains for follicular dendritic cell differentiation should help in their recognition. Correct characterization of this neoplasm is imperative, given its significant recurrent and metastatic potential.

\section{REFERENCES}

1. Monda L, Warnke R, Rosai J. A primary lymph node malignancy with features suggestive of dendritic reticulum cell differentiation. A report of 4 cases. Am J Pathol 1986;122: 562-72.

2. Nayler SJ, Verhaart MJ, Cooper K. Follicular dendritic cell tumour of the tonsil. Histopathology 1996;28:89-92.

3. Hollowood K, Stamp G, Zouvani I, Fletcher CD. Extranodal follicular dendritic cell sarcoma of the gastrointestinal tract. Morphologic, immunohistochemical and ultrastructural analysis of two cases. Am J Clin Pathol 1995;103:90-7.

4. Chan JK, Tsang WY, Ng CS. Follicular dendritic cell tumor and vascular neoplasm complicating hyaline-vascular Castleman's disease. Am J Surg Pathol 1994;18:517-25.

5. Perez-Ordonez B, Erlandson RA, Rosai J. Follicular dendritic cell tumor: report of 13 additional cases of a distinctive entity. Am J Surg Pathol 1996;20:944-55.

6. Chan JK, Fletcher CD, Nayler SJ, Cooper K. Follicular dendritic cell sarcoma. Clinicopathologic analysis of 17 cases suggesting a malignant potential higher than currently recognized. Cancer 1997;79:294-313.

7. Araujo VC, Martins MT, Salmen FS, Araujo NS. Extranodal follicular dendritic cell sarcoma of the palate. Oral Surg Oral Med Oral Pathol Oral Radiol Endod 1999;87:209-14.
8. Galati LT, Barnes EL, Myers EN. Dendritic cell sarcoma of the thyroid. Head Neck 1999;21:273-5.

9. Choi PC, To KF, Lai FM, Lee TW, Yim AP, Chan JK. Follicular dendritic cell sarcoma of the neck. Cancer 2000;89:664-72.

10. Andriko JW, Kaldjian EP, Tsokos M, Abbondanzo SL, Jaffe ES. Reticulum cell neoplasms of lymph nodes: A clinicopathologic study of 11 cases with recognition of a new subtype derived from fibroblastic reticular cells. Am J Surg Pathol 1998;22:1048-58.

11. Fornelli A, Mureden A, Eusebi V. Follicular dendritic cell tumor and unusual vascular lesion in lymph node with Castleman's disease. Description of a case. Pathologica 1998; 90:146-51.

12. Beham-Schmid C, Beham A, Jakse R, Aubock L, Hofler G. Extranodal follicular dendritic cell tumour of the nasopharynx. Virchows Arch 1998;432:293-8.

13. Dusenbery D, Watson CG. Fine-needle aspiration biopsy findings in a case of follicular dendritic cell tumor. Am J Clin Pathol 1996;106:689-92.

14. Fonseca R, Tefferi A, Strickler JG. Follicular dendritic cell sarcoma mimicking diffuse large cell lymphoma: a case report. Am J Hematol 1997;55:148-55.

15. Masunaga A, Nakamura H, Katata T, Furubayashi T, Kanayama Y, Yamada A, et al. Follicular dendritic cell tumor with histiocytic characteristics and fibroblastic antigen. Pathol Int 1997;47:707-12.

16. Vasef MA, Zaatari GS, Chan WC, Sun NC, Weiss LM, Brynes RK. Dendritic cell tumors associated with low-grade B-cell malignancies. Report of three cases. Am J Clin Pathol 1995; 104:696-701.

17. Guiter GE, Sanchez-Marull R, Sapia S, Zakowski MF, Gamboni MM. Fine-needle aspiration of a follicular dendritic-cell tumor: report of a case and review of the literature. Diagn Cytopathol 2000;22:238-42.

18. Herceg RJ, Nayar R, De Frias DV. Cytomorphologic appearance of follicular dendritic-cell tumor: A case report. Diagn Cytopathol 1999;20:237-40.

19. Schwarz RE, Chu P, Arber DA. Extranodal follicular dendritic cell tumor of the abdominal wall. J Clin Oncol 1999;17: $2290-2$.

20. Lee IJ, Kim SC, Kim HS, Bang D, Yang WI, Jung WH, et al. Paraneoplastic pemphigus associated with follicular dendritic cell sarcoma arising from Castleman's tumor. J Am Acad Dermatol 1999;40:294-7.

21. Shek TW, Liu CL, Peh WC, Fan ST, Ng IO. Intra-abdominal follicular dendritic cell tumour: a rare tumour in need of recognition. Histopathology 1998;33:465-70.

22. Shek TW, Ho FC, Ng IO, Chan AC, Ma L, Srivastava G. Follicular dendritic cell tumor of the liver. Evidence for an Epstein-Barr virus-related clonal proliferation of follicular dendritic cells. Am J Surg Pathol 1996;20:313-24.

23. Moriki T, Takahashi T, Wada M, Ueda S, Ichien M, Yamane $\mathrm{T}$, et al. Follicular dendritic cell tumor of the mesentery. Pathol Res Pract 1997;193:629-39.

24. Fisher C, Magnusson B, Hardarson S, Smith ME. Myxoid variant of follicular dendritic cell sarcoma arising in the breast. Annu Diagn Pathol 1999;3:92-8.

25. Pallesen G, Myhre-Jensen O. Immunophenotypic analysis of neoplastic cells in follicular dendritic cell sarcoma. Leukemia 1987;1:549-57.

26. Katano H, Kaneko K, Shimizu S, Saito T, Irie T, Mori S. Follicular dendritic cell sarcoma complicated by hyalinevascular type Castleman's disease in a schizophrenic patient. Pathol Int 1997;47:703-6.

27. Shah RN, Ozden O, Yeldandi A, Peterson L, Rao S, Laskin WB. Follicular dendritic cell tumor presenting in the lung: a case report. Hum Pathol 2001;32:745-9.

28. Chan AC, Chan KW, Chan JK, Au WY, Ho WK, Ng WM. Development of follicular dendritic cell sarcoma in hyaline- 
vascular Castleman's disease of the nasopharynx: tracing its evolution by sequential biopsies. Histopathology 2001;38: $510-8$.

29. Desai S, Deshpande RB, Jambhekar N. Follicular dendritic cell tumor of the parapharyngeal region. Head Neck 1999; 21:164-7.

30. Chan JK, Tsang WY, Ng CS, Tang SK, Yu HC, Lee AW. Follicular dendritic cell tumors of the oral cavity. Am J Surg Pathol 1994;18:148-57.

31. Chiaramonte MF, Lee D, Abruzzo LV, Heyman M, Bass BL. Retroperitoneal follicular dendritic cell sarcoma presenting as secondary amyloidosis. Surgery 2001;130:109-11.

32. Chang KC, Jin YT, Chen FF, Su IJ. Follicular dendritic cell sarcoma of the colon mimicking stromal tumour. Histopathology 2001;38:25-9.

33. Han JH, Kim SH, Noh SH, Lee YC, Kim HG, Yang WI. Follicular dendritic cell sarcoma presenting as a submucosal tumor of the stomach. Arch Pathol Lab Med 2000;124:1693-6.

34. Ryley NG, Bastert J, Ferguson DJ, Payne MJ. Follicular dendritic cell sarcoma of lymph node-report of fine needle aspiration (FNA) cytological appearances. Cytopathology 1999;10:335-40.

35. Lin O, Frizzera G. Angiomyoid and follicular dendritic cell proliferative lesions in Castleman's disease of hyalinevascular type: a study of 10 cases. Am J Surg Pathol 1997;21: 1295-306.

36. Hsu SM, Raine L, Fanger H. Use of avidin-biotin-peroxidase complex $(\mathrm{ABC})$ in immunoperoxidase techniques: a comparison between $\mathrm{ABC}$ and unlabeled antibody (PAP) procedures. J Histochem Cytochem 1981;29:577-80.

37. Chan J. Proliferative lesions of follicular dendritic cells: an overview, including a detailed account of follicular dendritic cell sarcoma, a neoplasm with many faces and uncommon etiologic associations. Adv Anat Pathol 1997;4:387-411.

38. Kaur A, Shetty SC, Prasad D, Nirmala V. Primary ectopic meningioma of the palatine tonsil—a case report. J Laryngol Otol 1997;111:179-81.

39. Schulz-Bischof K, Donath K, Hopker WW. Ectopic meningioma of the tonsil (see comments). Pathologe 1994;15:35860 .

40. Muller-Hermelink HK. Ectopic meningioma in the tonsil [letter]. Pathologe 1997;18:172-3.

41. Huszar M, Fanburg JC, Dickersin GR, Kirshner JJ, Rosenberg AE. Retroperitoneal malignant meningioma. A light microscopic, immunohistochemical, and ultrastructural study. Am J Surg Pathol 1996;20:492-9.
42. Raymond I, Al Saati T, Tkaczuk J, Chittal S, Delsol G. CNA.42, a new monoclonal antibody directed against a fixativeresistant antigen of follicular dendritic reticulum cells. Am J Pathol 1997;151:1577-85.

43. Steinman RM. The dendritic cell system and its role in immunogenicity. Annu Rev Immunol 1991;9:271-96.

44. Gerdes J, Stein H, Mason DY, Ziegler A. Human dendritic reticulum cells of lymphoid follicles: their antigenic profile and their identification as multinucleated giant cells. Virchows Archiv 1983;42:161-72.

45. Naiem M, Gerdes J, Abdulaziz Z, Stein H, Mason DY. Production of a monoclonal antibody reactive with human dendritic reticulum cells and its use in the immunohistological analysis of lymphoid tissue. J Clin Pathol 1983;36:167-75.

46. Parwaresch MR, Radzun HJ, Hansmann ML, Peters KP. Monoclonal antibody Ki-M4 specifically recognizes human dendritic reticulum cells (follicular dendritic cells) and their possible precursor in blood. Blood 1983;62:585-90.

47. Radzun HJ, Hansmann ML, Heidebrecht HJ, BodewadtRadzun S, Wacker HH, Kreipe H, et al. Detection of a monocyte/macrophage differentiation antigen in routinely processed paraffin-embedded tissues by monoclonal antibody Ki-M1P. Lab Invest 1991;65:306-15.

48. Al-Alwan MM, Rowden G, Lee TD, West KA. Fascin is involved in the antigen presentation activity of mature dendritic cells. J Immunol 2001;166:338-45.

49. Gaertner EM, Tsokos M, Derringer GA, Neuhauser TS, Arciero C, Andriko JA. Interdigitating dendritic cell sarcoma. A report of four cases and review of the literature. Am J Clin Pathol 2001;115:589-97.

50. Kraus MD, Haley JC, Ruiz R, Essary L, Moran CA, Fletcher CD. Juvenile xanthogranuloma: an immunophenotypic study with a reappraisal of histogenesis. Am J Dermatopathol 2001;23:104-11.

51. Jaffe R, DeVaughn D, Langhoff E. Fascin and the differential diagnosis of childhood histiocytic lesions. Pediatr Dev Pathol 1998;1:216-21.

52. Uehira K, Amakawa R, Ito T, Uehira T, Ozaki Y, Shimizu T, et al. A Hodgkin's disease cell line, KM-H2, shows biphenotypic features of dendritic cells and B cells. Int J Hematol 2001;73:236-44.

53. Pinkus GS, Pinkus JL, Langhoff E, Matsumura F, Yamashiro $\mathrm{S}$, Mosialos G, et al. Fascin, a sensitive new marker for Reed-Sternberg cells of Hodgkin's disease. Evidence for a dendritic or B cell derivation? Am J Pathol 1997;150:543-62.

54. Perez-Ordonez B, Rosai J. Follicular dendritic cell tumor: review of the entity. Semin Diagn Pathol 1998;15:144-54. 